\title{
Layanan Konseling Kelompok Tekhnik Assertive Training Dalam Menangani Konsep Diri Negatif Pada Peserta Didik
}

\author{
Laila Maharani, Tika Ningsih
}

Dosen dan Mahasiswa Fakultas Tarbiyah dan Keguruan, IAIN Raden Intanampung

Diterima: April 2015. Disetujui: Mei 2015. Dipublikasikan: Juni 2015

\begin{abstract}
Abstrak: Tujuan penelitian ini untuk mengetahui apakah layanan konseling kelompok assertive training dapat menangani konsep diri negatif pada peserta didik SMP Negeri 12 Bandar Lampung. Metode yang digunakan dalam penelitian ini adalah penelitian quasi eksperimen dengan desain One Group Pretest and Postest Design. Sampel dalam penelitian berjumlah 12 peserta didik kelas IX SMPN 12 Bandar Lampung yang memiliki konsep diri negatif. Tekhnik pengumpulan data dalam penelitian ini menggunakan skala konsep diri, wawancara, observasi, dan dokumentasi. Hasil analisis data menujukan bahwa terdapat peningkatan dalam menangani konsep diri negatif peserta didik sebelum dan setelah diberikan layanan konseling kelompok dengan tekhnik assertive training pada peserta didik.
\end{abstract}

Kata Kunci : Konseling Kelompok, Assertive Training, Konsep Diri

\section{Pendahuluan}

Lembaga pendidikan memiliki tanggung jawab yang besar terhadap keberhasilan peserta didik dalam belajar. Seperti yang diungkapkan oleh Mukhtar, dkk, salah satu media yang membantu remaja adalah sekolah. Sekolah diharapkan dapat mengelola secara efektif dan efisin perkembangan kualitas remaja untuk menjawab kebutuhan dan tantangan yang ada, serta mendidiknya agar mampu menyesuaikan diri dengan lingkungan (social skill).

Sekolah sarana untuk menumbuhkan dan mengembangkan potensi peserta didik, selain itu sekolah juga hendaknya membantu mengatasi masalah-masalah yang timbul dalam kegiatan belajar peserta didik dan penyesuaian peserta didik dilingkungan sekolah. Sekolah merupakan pendidikan sekunder. Anak remaja yang sudah duduk di bangku SMP atau SMA umumnya menghabiskan waktu sekitar 7 jam sehari disekolah. Tidak mengherankan jika pengaruh sekolah tentunya diharapkan positif terhadap perkembangan jiwa remaja karena sekolah adalah lembaga pendidikan. (Sarwono, 2013)

Sebagai mana telah dikemukakan oleh Prayitno, pengembangan kemanusiaan seutuhnya hendaknya mencapai pribadi - pribadi yang kediriannya matang, dengan kemampuan sosial yang menyejukkan, kesusilaan yang tinggi, dan keimanan serta ketaqwaan yang dalam. Tetapi kenyataan yang sering dijumpai adalah keadaan pribadi yang kurang berkembang dan rapuh. Sehubungan dengan hal itu, dalam proses pendidikan banyak dijumpai permasalahan yang dialami peserta didik anak-anak dan remaja. (Prayitno, 2004) Tohirin berpendapat bahwa, pelayanan bimbingan konseling sekolah sangat penting untuk dilaksanakan guna membantu peserta didik mengatasi berbagai masalah yang dihadapinya. (Tohirin, 2009)

Dalam dunia psikologi perkembangan, peserta didik yang berumur 12-15 tahun merupakan masa remaja awal. Umumnya individu mulai berusaha mengembangkan diri sebagai individu yang unik, tidak tergantung pada orang tua, dan fokus pada penerimaan diri terhadap bentuk dan kondisi fisik serta adanya konformitas yang kuat dengan teman sebaya. (Sunarto, 2008) Dalam buku psikologi perkembangan, masa remaja dibagi menjadi tiga bagian yaitu: pembagian 12-15 tahun adalah masa remaja awal, 15-18 tahun adalah masa remaja pertengahan, 18-21 tahun adalah masa remaja akhir. (Agustiani, 2009)

Maka dari itu peserta didik pada tingkat SMP termasuk kelompok usia remaja awal, 
karena umumnya berusia diantara 13-15 tahun merupakan masa pubertas yang memiliki sifat dan ciri-ciri yang sama dengan remaja pada umumnya. Pembentukankonsep diri pada remaja sangat penting karena akan mempengaruhi kepribadian, tingkah laku, dan pemahaman terhadap diri sendiri.

Masa remaja merupakan masa peralihan dari masa anak menuju masa dewasa. Hal ini memandang bahwa masalah yang dihadapi untuk menemukan jati dirinya, usaha penemuan jati diri remaja dilakukan dengan berbagai pendekatan. (Sunarto, Perkembangan Peserta Didik, 2008) Masa remaja berlangsung antara umur 12 tahun sampai dengan 21 tahun. (Ali, 2009)

Jadi dapat disimpulkan bahwa masa remaja adalah masa transisi dari anak-anak hingga dewasa yang berlangsung pada usia 12-21 tahun yang ditandai dengan ciri perubahan fisik dan masa pencarian identitas. Masa pubertas dianggap sebagai periode tumpang tindih. Hanya sedikit para pubertas yang mampu melewati periode pubertas dengan mengembangkan konsep diri yang menyenangkan. Adapun faktor-faktor yang mempengaruhinya adalah konsep diri yang tidak realistis, prilaku yang canggung sehingga membuat kecewa, sikap konsep diri yang negatif, prilaku anti sosial, menarik diri, sedikit bicara, agresif, dan tindak balas dendam.

Konsep diri adalah pandangan seseorang terhadap dirinya sendiri, mengenai siapa dia, apa peranannya dalam lingkungan dan apa yang ia inginkan. Menurut Stuart dan Laraia, konsep diri adalah semua nilai, ide, perasaan, prilaku, dan keyakinan yang kuat tentang diri sendiri yang mempengaruhi hubungan dengan orang lain. (Rita Yulifah, 2009) sedangkan william H. Fits menjelaskan konsep diri seseorang merupakan aspek penting dalam diri seseorang merupakan kerangka acuan dalam berinteraksi dengan lingkungan. Konsep diri berpengaruh terhadap tingkah laku seseorang, dengan mengetahui konsep diri, peserta didik akan lebih mudah meramalkan dan memahami tingkah laku yang dimiliki. (Sutoyo, 2012)

Bila individu menganggap dirinya mampu, maka sedapat mungkin individu melakukan tugas dengan baik, sebaliknya jika individu merasa dirinya tidak mampu, maka ia tidak akan bisa melakukan apapun. Pandangan individu terhadap dirinya sendiri sangat menentukan keberhasilan yang akan dicapai. Derajat positif-negatif dari konsep diri akan berpengaruh pada rasa percaya diri seseorang dan akhirnya mempengaruhi tingkah lakunya. Remaja dengan konsep diri positif akan lebih percaya diri dan merasa yakin bahwa dirinya memiliki andil terhadap segala sesuatu yang terjadi pada dirinya. Akibatnya ia akan lebih bersemangat untuk berusaha mencapai segala tujuannya.

Namun hasil observasi awal pada saat proses belajar gejala yang nampak adalah peserta didik menunjukkan sikap acuh karena merasa bahwa dirinya tidak disenangi guru dan temantemannya, mengeluh dengan kekurangan diri, bersikap pesimis, dan merasa terancam mudah marah yang menyebabkan perkelahian (emosional).

Menurut William D. Brooks dalam Anwar Sutoyo, menjelaskan bahwa ada beberapa ciri-ciri orang yang memiliki konsep diri negatif, yaitu: 1) Peka terhadap kritik; 2) mudah marah; 3) responsif terhadap pujian; 4) mengeluh, mencela atau merendahkan orang lain; 5) bersikap hiperkritis; 6) cenderung merasa tidak disenangi orang lain; 7) merasa tidak diperhatikan; 8) bersikap pesimis terhadap kompetisi seperti terungkap dalam keengganannya untuk bersaing dengan orang lain dan merasa tidak berdaya. (Sutoyo, 2012)

Sebaliknya orang yang memiliki konsep diri positif ditandai dengan ciri-ciri yaitu: 1) dapat menerima dirinya apa adanya dengan segala kekuatan dan kelemahannya; 2) ia tidak merasa terancam atau cemas menerima informasi baru tentang dirinya; 3) ia yakin dengan nilai dan prinsip yang ada pada dirinya; 4) mampu bertindak berdasarkan penilaian tanpa merasa bersalah; 5) ia mampu dan menyelesaikan masalah; 6) merasa aman dengan orang lain; 7) tidak peka terhadap kritikan; 8) ia merasa setara dengan orang lain. (Sutoyo, 2012)

Untuk mengatasi konsep diri negatif peserta didik, upaya yang bisa dilakukan antara lain dengan menerapkan tekhnik counseling kognitif, modeling, rasional emotif behavior teraphy, Johari Windows, dan Hidden self. Selain dari beberapa tekhnik di atas, tekhnik 
assertive training juga dapat menangani konsep diri peserta didik, Matheson mengemukakan beberapa laporan penelitan yang membuktikan bahwa assertive training dapat meningkatkan prilaku asertif, agresif, dan fasif. Dalam laporan tersebut para ahli yang mendukung latihan asertif menyatakan bahwa dampak layihan asertif pada peningkatan konsep diri adalah sangat dramatis, dimana kecemasan dapat dihilangkan dan keyakinan di dipertinggi. (Nursalim, 2014)

Assertive training merupakan tekhnik dalam konseling behavioral yang menitikberatkan pada kasus yang mengalami kesulitan dalam perasaan yang tidak sesuai dalam menyatakannya. Menurut Alberti dan Emmons prilaku assertive merupakan prilaku menegaskan diri yang positif yang mengusulkan kepuasan hidup pribadi dan meningkatkan kualitas hubungan dengan orang lain. Zastrow menyatakan assertive training dirancang untuk membimbing manusia menyatakan, merasa dan bertindak pada asumsi bahwa mereka memiliki hak untuk menjadi dirinya sendiri dan untuk mengekspresikan perasaannya secara bebas. (Nursalim, 2014)

Latihan assertive menggunakan prosedur-prosedur permainan peran. Suatu masalah yang khas yang bisa dikemukakan sebagai contoh adalah kesulitan peserta didik dalam memahami konsep dirinya, misalnya mudah tersinggung jika dikritik, merasa terancam dan mudah marah yang menyebabkan perkelahian, responsif terhadap pujian, mudah mengeluh dan putus asa mengenai kekurangan diri, bersikap hiperkritis, merasa tidak disenangi orang lain, kurang peracaya diri terkait kondisi fisik dan merasa dirinya bodoh, bersikap pesimis terhadap kompetisi. Tingkah laku menegaskan diri pertama-tama dipraktekkan dalam situasi permainan peran, dan dari sana diusahakan agar tingkah laku menegaskan diri itu dipraktekkan dalam situasi-situasi kehidupan yang nyata. (Corey, 2013)

Matheson mengemukakan beberapa laporan penelitian yang membuktikan bahwa assertive training dapat meningkatkan prilaku asertif, agresif, dan fasif. Dalam laporan tersebut para ahli yang mendukung latihan asertif menyatakan bahwa dampak latihan asertif pada peningkatan konsep diri adalah daramatis, dimana kecemasan dapat dihilangkan dan keyakinan diri dipertinggi. (Nursalim, 2014)

\section{Metode Penelitian}

Penelitian ini difokuskan pada layanan konseling kelompok tekhnik assertive training dalam menangani konsep diri negatif pada peserta didik di SMP Negeri 12 Bandar Lampung, sampel dalam penelitian ini adalah 12 peserta didik yang mengalami konsep diri negatif yang diambil dengan tekhnik purposive sampling, sedangkan populasi dalam penelitian ini 45 peserta didik kelas IX I dan L yang direkomendasikan oleh guru BK bahwa terdapat konsep diri yang negatif.

Penelitian ini menggunakan pendekatan kuantitatif sedangkan jenis penelitiannya adalah penelitian quasi eksperimen atau eksperimen semu dengan without control. Alasan peneliti menggunakan metode ini karena tidak menggunakan kelompok kontrol dan subyek tidak dipilih secara random. Hal tersebut sesuai dengan pendapat Seniati yang menyatakan bahwa eksperimen quasi berbeda dengan penelitian eksperimen karena tidak memenuhi tiga syarat utama dari suatu penelitian eksperimen yaitu manipulasi, kontrol dan randomisasi. (Arikunto, 2005)

\section{Hasil Dan Pembahasan}

Pelaksanaan penelitian ini dilaksnakan di Sekolah Menengah Pertama Negeri 12 Bandar lampung, dengan tujuan untuk menangani konsep diri negatif pada peserta didik. Konsep diri negatif akan berpengaruh terhadap pribadi peserta didik di sekolah maupun lingkungan. Hasil penelitian diperoleh melalui penyebaran instrument berupa angket konsep diri, hasil penyebaran instrument dijadikan analisis awal untuk perumusan layanan konseling 
assertive training dalam menangani konsep diri negatif pada peserta didik yang kemudian diuji cobakan guna memperoleh keefektifan. Setelah dilakukan penelitian dengan layanan konseling kelompok menggunakan tekhnik assertive training didapat hasil pretest, posttest, dan gain score pada tabel berikut:

\section{Tabel 1. Hasil Pretest dan Posttest Teknik Assertive Training Dalam Menangani} Konsep Diri

\begin{tabular}{ccccc}
\hline No & $\begin{array}{c}\text { Inisial } \\
\text { Peserta } \\
\text { Didik }\end{array}$ & $\begin{array}{c}\text { Pret } \\
\text { est }\end{array}$ & $\begin{array}{c}\text { Postt } \\
\text { est }\end{array}$ & $\begin{array}{c}\text { Score } \\
\text { Peningkatan }\end{array}$ \\
\hline $\mathbf{1}$ & N & 94 & 133 & $\mathbf{3 9}$ \\
\hline $\mathbf{2}$ & TADP & 82 & 130 & $\mathbf{4 8}$ \\
\hline $\mathbf{3}$ & DRR & 86 & 137 & $\mathbf{5 1}$ \\
\hline $\mathbf{4}$ & IMN & 90 & 120 & $\mathbf{3 0}$ \\
\hline $\mathbf{5}$ & EA & 83 & 118 & $\mathbf{3 5}$ \\
\hline $\mathbf{6}$ & AKR & 87 & 123 & $\mathbf{3 6}$ \\
\hline $\mathbf{7}$ & NSA & 93 & 135 & $\mathbf{4 2}$ \\
\hline $\mathbf{8}$ & YPDS & 85 & 127 & $\mathbf{4 2}$ \\
\hline $\mathbf{9}$ & MZR & 76 & 117 & $\mathbf{4 1}$ \\
\hline $\mathbf{1 0}$ & NI & 84 & 125 & $\mathbf{4 1}$ \\
\hline $\mathbf{1 1}$ & RW & 80 & 119 & $\mathbf{3 9}$ \\
\hline $\mathbf{1 2}$ & PLA & 77 & 115 & $\mathbf{3 8}$ \\
\hline $\mathbf{N}=\mathbf{1 2}$ & & $\sum$ & $\sum$ & $\sum \mathbf{4 8 2}$ \\
& & 1.01 & 1.499 & \\
\hline Rata-rata & & 7 & & $\mathbf{4 0 , 1 6}$ \\
\hline
\end{tabular}

Berdasarkan hasil perhitungan pretest 12 sampel peserta didik didapatkan hasil rata- rata konsep diri negatif dengan nilai 1.017:12 = 84,75 setelah dilakukan layanan konseling kelompok dengan tekhnik assertive training, konsep diri peserta didik cenderung meningkat dengan angka 1499:12 = 124,91 dengan skor peningkatan sebesar 40, 16. Jadi dapat disimpulkan bahwa konseling kelompok assretive training efektif untuk merubah konsep diri peserta didik, dilihat dari perubahan yang terjadi sebelum diberikan layanan.

Persentase Skor Perubahan tiap Indikator Konsep Diri Peserta Didik kelas IX SMP Negeri 12 Bandar Lampung Tahun Pelajaran 2015/2016 Sebelum dan Sesudah Mendapatkan Treatment mengalami perubahan setelah diberikan perlakuan, untuk persentase skor rata-rata juga meningkat sebesar $25,05 \%$ dari yang semula persentase rata-ratanya $52,95 \%$ menjadi $78 \%$.

Layanan konseling kelompok Assertive Training dalam menangani konsep diri negatif merupakan upaya pemberian bantuan kepada peserta didik dengan latihan prilaku asertif dengan membedakan prilaku pasif, asertif, dan agresif untuk dapat mengoptimalkan potensi yang dimiliki, mampu memandang dan memahami dirinya sendiri dengan baik tanpa merugikan orang lain. Peneliti menggunakan konseling kelompok dengan tekhnik Assertive training dalam menangani konsep diri negatif pada peserta didik kelas IX di Sekolah Menengah Pertama Negeri 12 Bandar Lampung, setelah 12 peserta didik mendapatkan treatment berupa konseling assertive training mengalami peningkatan yaitu terdapat 4 peserta didik dalam kategori sangat tinggi yitu N, TADP, DRR, dan NSA. Sedangkan 8 peserta didik dalam kategori tinggi yaitu IMN, EA, AKR, YPDS, MZR, NI, RW, dan PLA. Rata-rata skor konsep diri sebelum mengikuti layanan konseling kelompok assertive training meningkat menjadi 124,91 dengan selisih peningkatan 40,16.

Ditunjukkan pula dari hasil uji t dengan program SPSS 20 diperoleh thitung $=52.316$ lebih besar dari $t_{\text {tabel }}=1,796$ atau berada pada daerah penolakan Ho. Hal ini menunjukkan adanya peningkatan yang signifikan konsep diri setelah mengikuti kegiatan layanan konseling kelompok dengan tekhnik assertive training. Dengan demikian dapat dikatakan bahwa hipotesis yang menyatakan bahwa konseling kelompok assertive training dalam menangani 
konsep diri negatif pada peserta didik kelas IX di Sekolah Menengah Pertama Negeri 12 Bandar Lampung tahun pelajaran 2015/2016 diterima.

Dalam kegiatan ini peneliti memakai konseling kelompok dengan menggunakan topik tugas sehingga terarah apa yang menjadi tujuan dalam penelitian ini, dari topik-topik yang dibahas merupakan pengembangan dari aspek-aspek yang terdapat dalam skala konsep diri dari tiap pertemuan pertama sampai dengan pertemuan terakhir yang merupakan rangkaian satu kesatuan yang saling berkaitan dari setiap topik yang dibahas sehingga ketika mengikuti kegiatan ini dengan baik maka akan terjadi proses perubahan yang akan mereka alami terutama dalam proses menangani konsep diri negatif. Peserta didik yang mampu memahami konsep dirinya cenderung dapat menyesuaikan diri dengan baik. Misalnya jika individu itu diterima orang lain, dihormati dan disenangi karena keadaan dirinya. Sebaliknya bila orang lain selalu meremehkan, menyalahkan dan menolaknya, individu akan cenderung tidak menyenangi dirinya. Melalui pengalaman interaksi dengan orang lain dan cara orang lain memperlakukan individu tersebut akan memenangkan pantulan tentang dirinya dan akhirnya membentuk gagasan dalam dirinya seperti apakah dirinya sebagai pribadi serta akan terbentuk jati diri peserta didik yang sebenarnya dan memiliki kepribadian yang sehat sesuai dengan perkembangannya.

Berdasarkan pemaparan tersebut, dapat disimpulkan bahwa konseling kelompok assertive training efektif dalam menangani konsep diri negatif pada peserta didik. Meskipun begitu, hendaknya perlu ditindak lanjut, yaitu peserta didik diharapkan harus mampu mempertahankan keterampilan yang telah peserta didik memiliki yang diperoleh dari proses konseling dan secara otomatis dapat menjadi kebiasaan di kehidupan sehari- hari tanpa pemberi penguatan positif yang dipelajari selama mendapatkan konseling kelompok assertive training.

\section{Kesimpulan}

Berdasarkan hasil penelitian "layanan konseling kelompok dengan tekhnik assertive training dalam menangani konsep diri negatif pada peserta didik kelas IX di Sekolah Menegah Pertama Negeri 12Bandar Lampung" dapat disimpulkan bahwa hasil perhitungan rata-rata skor konsep diri sebelum mengikuti layanan konseling kelompok assertive training adalah 84,75 dan setelah mengikuti layanan konseling kelompok assertive training menjadi 124,91 dengan selisih peningkatan 40,16. Dari hasil uji-t menggunakan program SPSS versi 20, bahwa t adalah 52,316, mean difference adalah 112,91667,95 \% confidence interval of the difference, lower $=108,1662$ dan upper $=117,6672$. Kemudian $t_{\text {hitung }}$ dibandingkan dengan $\mathrm{t}_{\text {tabel }} \mathrm{dk}=11$, dengan ketentuan $t_{\text {hitung }}$ lebih besar dari $t_{\text {tabel }}(52,316 \geq 1,796)$, artinya konsep diri peserta didik terdapat perubahan setelah diberikan layanan konseling kelompok assertive training.

Dilihat dari ketentuan $t_{\text {hitung }}>t_{\text {tabel, }}$, hasil perhitungan lebih besar $t_{\text {hitung }}>t_{\text {tabel, }}$ dengan demikian dapat disimpulkan bahwa hipotesis nihil (Ho) ditolak dan hipotesis kerja (Ha) yang berbunyi konsep diri negatif dapat ditangani dengan menggunakan layanan konseling kelompok dengan tekhnik assertive training pada peserta didik kelas IX SMPN 12 Bandar Lampung tahun pelajaran 2015/2016 diterima.

\section{Daftar Pustaka}

Agustiani, H. (2009). Psikologi Perkembangan Pendekatan Ekologi Kaitannya dengan Konsep Diri dan Penyesuaian Diri Pada Remaja. Bandung: Refika Aditama.

Ali, M. (2009). Psikologi Remaja Perkembangan Peserta Didik. Jakarta: Bumi Aksara.

Arikunto. (2005). Manajemen Penelitian. Jakarta: Asdi Mahastya.

Corey, G. (2013). Teori dan Praktek Konseling dan Psikoterapi. Bandung: Rafika Aditama. 
Nursalim, M. (2014). Strategi dan Intervensi Konseling. Jakarta: Indeks.

Prayitno. (2004). Dasar-dasar Bimbingan dan Konseling. Jakarta: Rineka Cipta.

Rita Yulifah, T. J. (2009). Komunikasi dan Konseling dalam kebidanan. Jakarta: Salemba Medika.

Sarwono, S. W. (2013). Pengantar Psikologi Umum. Jakarta: Rajawali Pers.

Sunarto, A. H.(2008). Perkembangan Peserta Didik. Jakarta: Rineka Cipta.

Sunart A. H. (2008). Perkembangan Peserta Didik. Jakarta: Rineka Cipta.

Sutoyo, A. (2012). Pemahaman Individu. Yogyakarta : Pustaka Pelajar.

Tohirin. (2009). Bimbingan dan Konseling di Sekolah dan Madrasah (Berbasis Integrasi). Jakarta: Rajawali Pers. 